\title{
Effect of Temperature, Leaf Wetness, and Rainfall on the Production of Guignardia citricarpa Ascospores and on Black Spot Severity on Sweet Orange
}

\author{
Renato F. Reis ${ }^{1}$, Lavern W. Timmer ${ }^{2}$ \& Antonio de Goes ${ }^{1}$ \\ ${ }^{1}$ Universidade Estadual Paulista, FCAV, Jaboticabal, SP, Rodovia Prof. Paulo Donato Castellane, km 5, s/no \\ CEP14884-900, Jaboticabal, SP, Brazil, Fax (16) 3202-4275, e-mail: reisferrari@hotmail.com; \\ ${ }^{2}$ University of Florida, IFAS, Department of Plant Pathology, Citrus Research and Education Center, \\ 700 Experiment Station Road, Lake Alfred, FL, 33850, USA
}

(Accepted for publication on 20/10/2005)

Author for correspondence: Renato F. Reis

REIS, R.F., GOES, A. \& TIMMER, L.W. Effect of temperature, leaf wetness, and rainfall on the production of Guignardia citricarpa ascospores and on black spot severity on sweet orange. Fitopatologia Brasileira 31:029-034. 2006.

\begin{abstract}
The black spot of citrus (Citrus sp.) is caused by Guignardia citricarpa with ascospore production depending on temperature, leaf wetness, and rainfall. The number of ascospores produced was monitored using a spore trap and climatic factors were recorded using an automated meteorological station of 'Natal' and 'Valencia' sweet orange (Citrus sinensis) orchards in Mogi Guaçu in the state of São Paulo, Brazil, from November 2000 to March 2001. The fruits were bagged to prevent infection and the bags removed from different sets of fruit for one week during each of the 18 weeks of the season in both orchards. Ascospores were produced during the entire experimental period, from spring through summer, primarily after rain events. In both orchards, ascospore production reached a peak in January and February. Ascospore production was related to leaf wetness only in the Natal orange orchard but was not related to total rainfall or temperature in either orchard. Disease was most severe on fruit exposed the $7^{\text {th }}, 8^{\text {th }}$, and $13^{\text {th }}$ weeks after beginning the experiment in both cultivars as well as after the $16^{\text {th }}$ week for 'Natal'. There was a strong relationship between disease severity and total rainfall for both orchards and a weak correlation between temperature and severity in the 'Natal' block only. There was no relationship between severity and leaf wetness or ascospore numbers.
\end{abstract}

Additional keywords: Citrus sinensis, Phyllosticta citricarpa, climatic factors.

\begin{abstract}
RESUMO
Efeito da temperatura, molhamento foliar e chuva na produção de ascósporos de Guignardia citricarpa e severidade da pinta preta dos citros em laranja Natal e Valência

A pinta preta dos frutos cítricos (Citrus sp.)é causada por Guignardia citricarpa e a produção de ascósporos depende da temperatura, molhamento foliar e chuva. O número de ascósporos foi monitorado usando uma armadilha de esporos e os fatores climáticos foram avaliados usando uma estação automotizada em pomares de laranja (Citrus sinensis) Natal e Valência, no período de novembro de 2000 a março de 2001 no município de Mogi-Guaçu/SP, Brasil. Em ambos os pomares, os frutos foram ensacados para prevenir a infecção natural, e os sacos foram removidos semanalmente em diferentes estádios de desenvolvimento dos frutos durante 18 semanas. Ascósporos foram produzidos durante todo o período do experimento especialmente primeiramente depois da ocorrência de chuvas. Em ambos os pomares o pico de produção de ascósporos ocorreu em janeiro e fevereiro. A produção de ascósporos foi correlacionada com o molhamento foliar apenas para o pomar de laranja Natal, mas não foi correlacionada com o total de chuva ou temperatura para as duas variedades. A doença foi mais severa em frutos expostos na $7^{\mathrm{a}}, 8^{\mathrm{a}}$ e $13^{\mathrm{a}}$ semana, após o início do experimento para ambas variedades e, na $16^{\text {a }}$ semana para a variedade Natal. Verificou-se uma forte correlação entre severidade da doença e quantidade total de chuva para ambas variedades e uma fraca correlação entre temperatura e severidade para o pomar de laranja Natal. Não houve correlação entre severidade e molhamento foliar ou com o número de ascósporos.
\end{abstract}

Palavras-chave adicionais: Citrus sinensis, Phyllosticta citricarpa, fatores climáticos.

\section{INTRODUCTION}

The black spot disease of citrus (Citrus sp.), caused by Guignardia citricarpa Kiely, was first described by Kiely (1949), in New South Wales, Australia. This disease is found in Africa (Mozambique, Zimbabwe, Swaziland, and South Africa), Asia (China, Indonesia, Taiwan, Hong-Kong,
Philippians, and Japan), Australia, and in the Americas (Argentina, Brazil, and Peru) (Kotze, 2000; Peres \& Timmer, 2003).

For many years, pathogenic and nonpathogenic forms of G. citricarpa have been recognized (McOnie, 1964a; Kotze, 2000). However, these strains differ in their growth rate, colony type, color, conidial morphology, and molecular 
characteristics and are now considered separate species (Baayen et al., 2002). Species-specific molecular probes have been designed and are useful in differentiating the black spot pathogen, G. citricarpa, from the non pathogenic species, $G$. mangiferae (Bonants et al., 2003). Guignardia mangiferae has a broad host range and occurs on many woody species including citrus, whereas G. citricarpa only affects citrus.

With the exception of sour orange (Citrus aurantium L.) and its hybrids and Tahiti limes [C. latifolia (Yu. Tanaka) Tanaka], almost all Citrus spp., especially late maturing cultivars, are susceptible to this disease (Kotze, 1964, 2000). Several different types of black spot symptoms including hard spot, virulent spot, and false melanose occur on affected fruit and reduce its value for the fresh market (Kotze, 2000). Premature fruit drop due to black spot causes significant yield loss in Brazil, and probably in other citrus regions of the world.

In South Africa and Australia, ascospores have been shown to be the main inoculum source (Kiely, 1949; McOnie, 1964a; Kellerman \& Kotze, 1977; Kotze, 1981; Smith, 1996). Pseudothecia are produced in fallen and decomposing leaves, and ascospores of G. citricarpa can be produced during the entire year. Their frequency and abundance depends on alternating periods of drying or wetting of leaves (McOnie, 1964b; Huang \& Chang, 1972; Kotze, 1964, 1981; Schutte et al., 1997). In this pathosystem, rain is essential for ascospore release of G. citricarpa (Huang \& Chang, 1972; Kotze, 2000; Fogliata et al., 2001).

In 1992, a severe outbreak of black spot was identified in Siciliano lemon (C. limon L.) and late maturing sweet orange [Citrus sinensis (L.) Osbeck] orchards in Conchal and Engenheiro Coelho, São Paulo State, Brazil (Goes \& Feichtenberger, 1993; Goes, 1996), and is also currently found in certain regions of this state. Sweet orange fruits are susceptible until around 24 weeks after petal fall (Baldassari, 2001; Reis et al., 2003). This long period of fruit susceptibility makes successful disease control difficult and increases citrus production costs as a consequence of the high number of fungicide applications needed (Fagan \& Goes, 1999).

Determining the effects of temperature, rainfall, leaf wetness, and relative humidity on the formation, release, and germination of ascospores in different pathosystems has been the focus of many researchers worldwide (Rowe \& Beute, 1975; Sutton, 1981; Pinkerton et al., 1998a,b; Hartman et al., 1999; MacHardy et al., 2001; Mondal \& Timmer, 2002). Among these pathosystems, the Malus spp.Venturia inaequalis interaction has been the most studied because of the importance of ascospores for epidemics of apple scab (Hartman et al., 1999; MacHardy et al., 2001). While ascospore production has been monitored in previous studies in Brazil (Reis, unpublished) and elsewhere (Huang \& Chang, 1972; Smith, 1996; Fogliata et al., 2001), the relative amounts of infection occurring at different times of the year have not been studied in relation to ascospore release and weather factors in the major citrus producing area in
São Paulo. This information is important for a better understanding of the pathosystem and for the choice for disease control.

The purpose of this study was to determine the effect of temperature, leaf wetness, and rainfall on the production of G. citricarpa ascospores and on disease severity in Natal and Valencia orange orchards under natural conditions. In addition, we tried to relate the numbers of G. citricarpa ascospores captured and disease severity on fruits of Natal and Valencia sweet orange.

\section{MATERIAL AND METHODS}

\section{Ascospore monitoring}

Experiments were carried out from November 2000 to March 2001 in two orchards located near Mogi-Guaçu, São Paulo State, Brazil. Orchards consisted of 14 year old Natal and Valencia sweet oranges on Volkamer lemon (Citrus volkameriana Tan. \& Pasq.) rootstock planted at $8 \times 5 \mathrm{~m}$ spacing. The orchards were about $2 \mathrm{~km}$ apart and the Natal orchard was located in a low area subject to fogs. A Quest volumetric spore trap system (Quest Developments, Pretoria, South Africa) with a capacity of $20 \mathrm{l} / \mathrm{h}$ and discs for ascospore monitoring during a cycle of eight days was placed in each orchard. Periodically, discs were replaced and taken to the laboratory and ascospores counted on a compound microscope at 400X magnification. Ascospores were stained with cotton blue in lactic acid (1:600 wt/vol). Ascospore identification of G. citricarpa was based on their morphology as described by Sutton \& Waterston (1966). However, ascospores of G. citricarpa and G. mangiferae are not distinguishable (Baayen et al., 2002; Peres \& Timmer, 2003).

The spore trap used had discs with eight sections per day which were divided into 3-h time periods each. When the readings were conducted, ascospores were counted in four passes of one field width each in each 3-h time period. The number of counts varied depending on the rainfall. When rainfall occurred, all 3-h periods were counted the day of the rain and the two days following. During extended dry periods, few ascospores were captured and only the sections at midnight and noon were counted on days $1,3,6$, 7 , and 8 after installation of the trap. The reading method was based on a previous study that demonstrated that few or no ascospores were released during dry periods (Reis, unpublished). Counts were adjusted by dividing, by the proportion of the area counted so that they represented equivalent numbers per week.

\section{Determination of leaf wetness, temperature, and rainfall}

An automated meteorological station, Adcon Telemetry model (Adcon Telemetry Inc., Santa Rosa, California, USA) with sensors for air temperature, leaf wetness, and precipitation was installed at each location in the period from November 2000 to March 2001. Leaf wetness sensors were placed within the tree canopy. 


\section{Determination of black spot severity on fruit}

In each orchard 36 trees were used for this evaluation. After $34^{\text {th }}$ of petal fall, on 24 October 2000, the plants selected were sprayed with benomyl at $0.25 \mathrm{~g}$ a.i.l. ${ }^{-1}$ of water, plus $0.5 \%$ Assist ${ }^{\circledR}$ BASF mineral oil $(756 \mathrm{ml} / \mathrm{l})$ to eliminate any latent infections (Kotze, 1981) that may have occurred prior to initiation of the experiments. After spraying, 300 arbitrarily selected fruits on each of the 36 trees were covered with 13 x $21 \mathrm{~cm}$ waxed paper bags when the fruits were about $0.4 \mathrm{~cm}$ in diameter. Since considerable natural fruit drop occurs, especially when fruit is $2-3 \mathrm{~cm}$ in diameter, it was necessary to bag many more fruits than were finally evaluated. Later, the paper bags from ten fruits on each of 36 different trees were removed weekly to allow exposure to natural infection for one week. After one week of exposure to natural infection, these fruits were rebagged and tagged for evaluation when the fruit was mature. This procedure was continued each week throughtout 8 March 2001. One set of fruit was left unbagged for the entire season and another set remained bagged for the entire time.

Disease severity was evaluated on 9 September 2001 using ten fruits from each of 36 trees for each week, using the method of Fagan \& Goes (1999). The scale used was from 0 to 3, where: 0 - symptoms absent; 1 - from one to three small, individual lesions; 2 - from four to six small, well-defined lesions; 3 - more than sis well-defined lesions. False melanose symptoms which are caused by pycnidiospore infection (Kotze, 1986; Spósito, 2003) were not considered in the ratings.

\section{Data analysis}

The total number of ascospores collected per week, average weekly temperatures, the average number of leaf wetness hours per day during the week and total weekly rainfall (mm) were plotted from 2 November 2000 to 8 March 2001. Linear regression analyses were conducted between weather factors and ascospore numbers and with disease severity using the GLM procedure of SAS version 6.0 (SAS Institute, Cary, North Carolina, USA). Various transformations of the data were attempted to reduce the variances and improve the fit to curves.

\section{RESULTS}

\section{Ascospore release}

Ascospore release was similar in the Natal and Valencia sweet orange orchards, but some differences were noted (Figure 1). High numbers of ascospores were observed from weeks 12 to 15 in the Natal block and in weeks 13 and 15 in the Valencia block. Moderate numbers were observed in weeks 7, 8 and 9 in the Natal block and in weeks 7, 8, 9, 12, 16 and 18 in the Valencia block. Ascospore capture was low in other weeks, but spores were present nearly every week in both orchards, except in week 6 in the Valencia orchard.

\section{Disease severity}

Black spot severity was generally greater in the Natal than in the Valencia block. Disease severity was greatest when fruit remained unbagged during weeks 4, 7, 8, 13, and 16 on Natal and during weeks 7, 8, and 13, on Valencia (Figure 1). Fruit bagged for the entire 18-week period had ratings of 0.07 on Natal and 0.04 on Valencia. A small amount of infection in the bagged controls may have occurred on a few fruits, where bags were temporarily broken. Fruit that was never bagged had ratings of 2.55 on Natal and 2.31 on the Valencia.

\section{Weather effects}

The average weekly temperature did not vary greatly throughout the 18-week period and usually ranged from 22 to $25^{\circ} \mathrm{C}$ (Figure 1). Temperatures were slightly higher during weeks with low rainfall and slightly lower during weeks with high rainfall. Rainfall varied considerably with almost no rain some weeks to over $200 \mathrm{~mm}$ in others. Wetness duration varied from a low of only about $3 \mathrm{~h}$ /day in week one in the Valencia orchard to nearly $14 \mathrm{~h} /$ day during several weeks.

Neither temperature nor rainfall amount was related to the number of ascospores captured in either the Natal or the Valencia block (Table 1). Ascospore capture was significantly related to the duration of leaf wetness in the Natal block $(P<0.05)$, but weakly related in the Valencia block. Where ascospore counts were transformed to $\log _{10}$ prior to regression analysis, ascospore numbers were more strongly related to leaf wetness in both the Natal block $\left(\mathrm{R}^{2}=0.36, P=\right.$ $0.01)$ and in the Valencia block $\left(\mathrm{R}^{2}=0.21, P=0.05\right)$. No other transformations increased the regression coefficients.

Rainfall total was highly related $(P<0.01)$ to disease severity in both the Natal and Valencia blocks (Table 1). The number of ascospores trapped had no relationship to disease severity in either block. There was a weak negative relationship between temperature and disease severity in the Natal block. However, this was probably due to the negative relationship between rainfall and temperature. There was no relationship between leaf wetness and disease severity in either block.

\section{DISCUSSION}

The ascospores of $G$. citricarpa are formed on decomposing leaves on the soil surface as are ascospores of some other Ascomycotina (Hartman et al., 1999; MacHardy et al., 2001; Mondal \& Timmer, 2002). Pseudothecia develop in 40 to 180 days after leaf drop depending on the frequency of wetting and the temperature (Kotze, 2000). Ascospore release is triggered by rainfall or irrigation (Kotze, 2000). As little as $3 \mathrm{~mm}$ of rainfall can trigger ascospore release (McOnie, 1964b).

The disease cycle of citrus black spot is similar to that of citrus greasy spot (Mondal \& Timmer, 2002) and not unlike that of other diseases caused by Ascomycetes such as Venturia inaequalis (Cooke) G. Wint. (Hartman et al., 1999; MacHardy et al., 2001), Anisogramma anomala (Peck) E. Müller (Pinkerton et al., 1998a,b), and Calonectria 

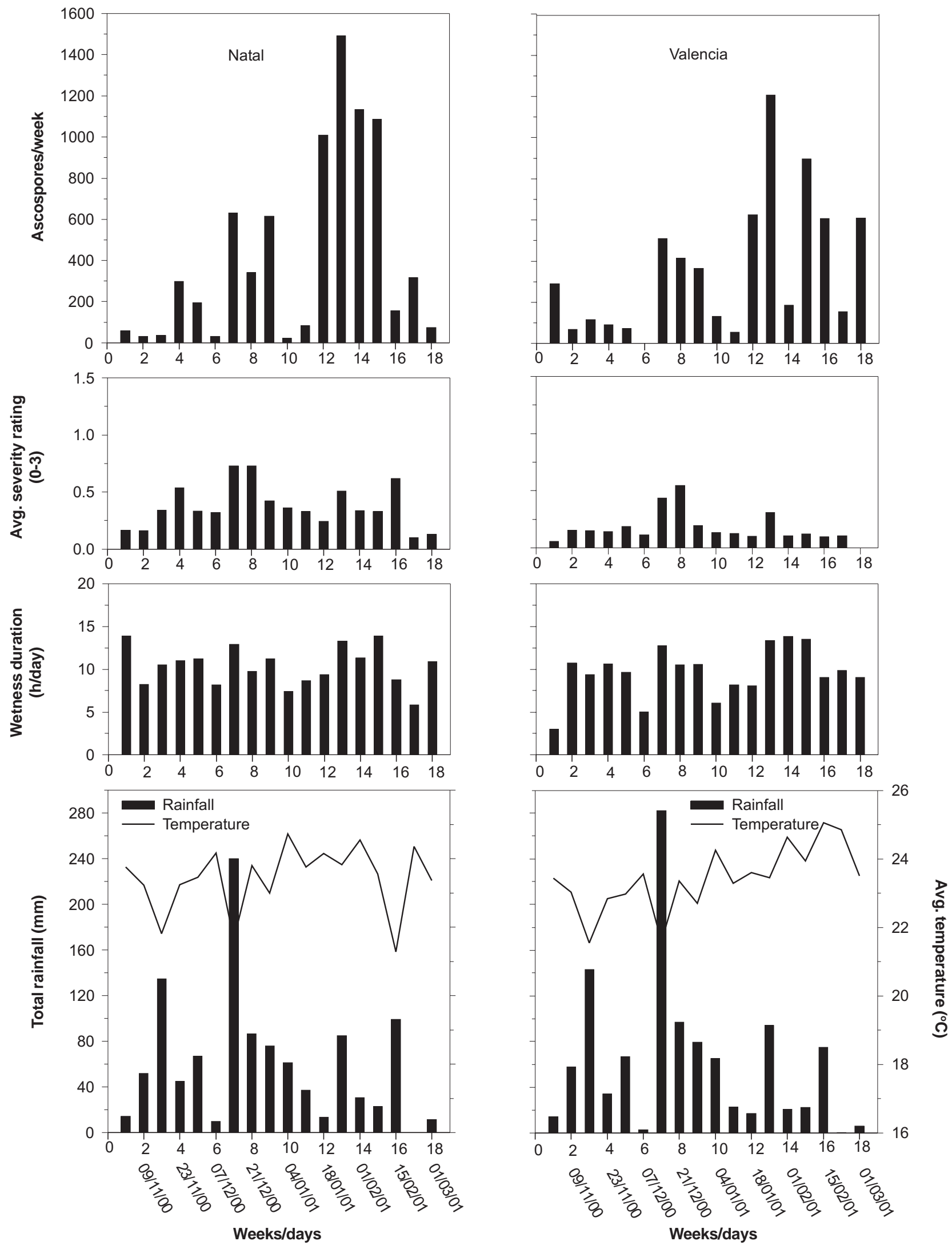

FIG. 1 - Black spot severity on fruit, number of ascospores of Guignardia citricarpa captured, leaf wetness duration, rainfall, and temperature in orchards of Natal and Valencia orange (Citrus sinensis) near Mogi-Guaçu, São Paulo, Brazil for 18 weeks from November 2000 to March 2001. The severity rating on fruit that was unbagged the entire time was 0.07 for Natal and 0.04 for Valencia. On fruit bagged the entire time, black spot severity ratings were 2.55 and 2.31 for Natal and Valencia, respectively. 
Effect of temperature, leaf wetness, and rainfall on the production...

TABLE 1 - Linear regression analysis of the effect of weekly average temperature, total hours of leaf wetness and rainfall amount on number of Guignardia citricarpa ascospores captured and between the same effects and weather factors on number of ascospores or disease severity of Natal and Valencia sweet orange (Citrus sinensis)

\begin{tabular}{|c|c|c|c|c|c|c|}
\hline \multirow{3}{*}{ Factor } & \multicolumn{6}{|c|}{ Ascospores captured } \\
\hline & \multicolumn{2}{|c|}{ Slope (b) } & \multicolumn{2}{|c|}{$R^{2}$} & \multicolumn{2}{|c|}{$P$} \\
\hline & Natal & Valencia & Natal & Valencia & Natal & Valencia \\
\hline Temperature & 89.18 & 42.34 & 0.03 & 0.01 & 0.45 & 0.63 \\
\hline Leaf wetness & 100.88 & 49.83 & 0.24 & 0.19 & 0.03 & 0.07 \\
\hline \multirow[t]{2}{*}{ Rainfall } & 0.39 & 0.78 & 0.002 & 0.02 & 0.84 & 0.52 \\
\hline & \multicolumn{6}{|c|}{ Disease severity } \\
\hline \multirow[t]{2}{*}{ Factor } & \multicolumn{2}{|c|}{ Slope (b) } & \multicolumn{2}{|c|}{$R^{2}$} & \multicolumn{2}{|c|}{$P$} \\
\hline & Natal & Valencia & Natal & Valencia & Natal & Valencia \\
\hline Temperature & -3.00 & -1.84 & 0.21 & 0.15 & 0.05 & 0.11 \\
\hline Leaf wetness & 0.67 & 0.61 & 0.05 & 0.16 & 0.33 & 0.10 \\
\hline Rainfall & 0.08 & 0.04 & 0.51 & 0.48 & $<0.01$ & $<0.01$ \\
\hline Ascospores & 15.56 & 15.92 & 0.04 & 0.04 & 0.39 & 0.39 \\
\hline
\end{tabular}

crotalariae (Coos) Bell \& Sobers (Rowe \& Beute, 1975). As with Mycosphaerella citri Witheside, ascocarp development requires extended periods of wetting and drying (Mondal \& Timmer, 2002). However, as with most of the other Ascomycetes, ascospores may be released quickly with minimal amounts of wetting once mature.

Ascospore release by G. citricarpa in South Africa occurs from November to March during the rainy season with the highest numbers in December to January. In lemon orchards in Argentina, the peak of ascospore production also occurs in December to January (Fogliata et al., 2001). Previous work (Goes \& Feichtenberger, 1993) indicated that ascospores were produced from October to June in Brazil. In our study, comparatively low to moderate numbers were produced from October to March with peak ascospore production in January and February in both orchards.

In our study, the number of ascospores captured was not related to temperature or to total rainfall during the week, but was related to the duration of leaf wetness. In that respect, G. citricarpa behaves similarly to M. citri (Whiteside, 1974; Mondal \& Timmer, 2002). Even a small amount of rain triggers release of ascospores and at least some ascospores continue to be released as long as the leaves are moist. There was no relationship to total rainfall because a small amount of rain triggers release of ascospores and additional rainfall produces no more spores.

The severity of the disease did not vary greatly during the 18 weeks of the study. The low amount of infection in the first two weeks may have been due to the earlier benomyl application. The amount of disease was strongly related to rainfall which is logical since rain is needed to trigger ascospore release. However, there was no significant relationship between ascospore release and rainfall amount. Severity was weakly and negatively related to temperature, but that relationship is probably due to the negative relationship between temperature and rain. Even though the number of ascospores captured varied considerably, there was no relationship between ascospore numbers and severity.
Similar results were observed in South Africa (Smith, 1996). Apparently there are sufficient numbers present all summer to infect fruit if conditions are favorable. Ascospores of $G$. mangiferae and G. citricarpa are not distinguishable on spore trap slides, but G. mangiferae is not commonly isolated from orchards with black spot in South Africa (Meyer et al., 2001). Thus, we presume that most of the ascospores captured in the groves that were severely infected with black spot were those of G. citricarpa. However, we cannot preclude the possibility that sufficient ascospores of $G$. mangiferae were present at times to confuse the relationship between ascospore numbers and disease severity.

In this study, we hoped to define periods of the year when fruit was less susceptible, conditions were less favorable, or ascospores were unavailable in order to advise growers how to more effectively time fungicide applications. Fruit in South Africa is considered to be susceptible for four to five months after petal fall (Kotze, 1964, 2000). In Brazil, fruit appeared to be susceptible for at least that long, since our study continued for at least five months after petal fall. The results of evaluations with copper fungicides indicated that at least one preventive spray a month is needed to control black spot in Brazil (Reis et al., 2003). When fungicide applications were omitted in monthly spray programs, black spot was slightly more severe when sprays were omitted in November than when sprays were omitted in March or April. However, it appears that some infection occurs throughout the spring and summer and we did not succeed in identifying key periods when fungicide sprays may be reduced or need to be intensified.

Additional studies should be conducted to determine the patterns of spore release and infection under other conditions. It would be valuable to do similar studies in drier areas in northern São Paulo, cooler regions in southeastern São Paulo, or other areas further south.

\section{Acknowledgments}

This work was supported by Fundação de Amparo à 
Pesquisa do Estado de São Paulo (FAPESP). We would like to thank Sete Lagoas Farm for supplying the experimental area, to Fundo de Defesa da Citricultura (FUNDECITRUS), and to Prof. Dr. Gener Tadeu Pereira of FCAV/Jaboticabal/ SP for statistical analysis.

\section{LITERATURE CITED}

BAAYEN, R.P., BONANTS, P.J.M., VERKLEY, G., CARROLL, G.C., VAN DER AA, H.A., DE WEERDT, M., VAN BROUWERSHAVEN, I.R., SCHUTTE, G.C., MACCHERONI JR., W., GLIENKE DE BLANCO, C. \& AZEVEDO, J.L. Nonpathogenic isolates of the citrus black spot fungus, Guignardia citricarpa, identified as a cosmopolitan endophyte of woody plants, $G$. mangiferae (Phyllosticta capitalensis). Phytopathology 92:464477. 2002.

BALDASSARI, R.B. Influência de frutos sintomáticos de uma safra na incidência da Guignardia citricarpa na safra subseqüente e período de suscetibilidade de frutos de laranjeiras 'Natal' e 'Valência'. (Dissertação de Mestrado). Jaboticabal. Faculdade de Ciências Agrárias e Veterinárias, Universidade Estadual Paulista, 2001.

BONANTS, P.J.M., CARROLL, G.C., DE WEERDT, M., BROUWERSHAVEN, I.R. \& BAAYEN, R.P. Development and validation of a fast PCR-based detection method for pathogenic isolates of the citrus black spot fungus, Guignardia citricarpa. European Journal of Plant Pathology 109:503-513. 2003.

FAGAN, C. \& GOES, A. Efeito da severidade da mancha preta dos frutos cítricos causada por Guignardia citricarpa na queda de frutos de laranja 'Natal'. Fitopatologia Brasileira 24:282. 1999. (Resumo).

FOGLIATA, G.M., PLOPER, L.D. \& CANTON, N. Dinâmica de liberación de ascosporas de Guignardia citricarpa en Tucumán, Argentina. Fitopatologia Brasileira 26:469. 2001. (Resumo).

GOES, A. Deteç̧ão da fase perfeita Guignardia citricarpa em frutos cítricos do Estado de São Paulo. Fitopatologia Brasileira 21:361. 1996. (Resumo).

GOES, A. \& FEICHTENBERGER, E. Ocorrência da mancha preta causada por Phyllosticta citricarpa (McAlp) Van der Aa (Guignardia citricarpa Kiely) em pomares cítricos do Estado de São Paulo. Fitopatologia Brasileira 21:318. 1993. (Resumo).

HARTMAN, J.R., PARISI, L. \& BAUTRAIS, P. Effect of leaf wetness duration, temperature, and conidial inoculum dose on apple scab infections. Plant Disease 83:531-534. 1999.

HUANG, C.S. \& CHANG, S.L. Leaf infection with citrus black spot and perithecial development in relation to ascospore discharge of Guignardia citricarpa Kiely. Journal of Taiwan Agriculture Research 21:256-263. 1972.

KELLERMAN, C.R. \& KOTZE, J.M. The black spot diseases of citrus and its control in South Africa. Proceedings of the International Society of Citriculture 3:992-996. 1977.

KIELY, T.B. Black spot of citrus. Agricultural Gazette 1:17-19. 1949. KOTZE, J.M. Studies on the black spot disease of citrus caused by Guignardia citricarpa Kiely, with particular reference to its epiphytology and control at Letaba. (Ph.D. Thesis) Pretoria., University of Pretoria. 1964.
KOTZE, J.M. Epidemiology and control of citrus black spot in South Africa. Plant Disease 65:945-950. 1981.

KOTZE, J.M. Black spot. In: Timmer L.W., Garnsey, S.M. \& Graham, J.H. (Eds.) Compendium of Citrus Diseases St. Paul:APS Press 2000, $2^{\text {nd }}$ ed., pp.10-12 .

MacHARDY, W.E., GADOURY, D.M. \& GESSLER, C. Parasitic and biological fitness of Venturia inaequalis: relationship to disease management strategies. Plant Disease 85:1036-1051. 2001.

MEYER L., SLIPPERS, B., KORSTEN, L. \& KOTZE, L.M. Two distinct Guignardia species associated with citrus in South Africa. South African Journal of Science 97:191-194. 2001.

McONIE, K.C. Source of inoculum of Guignardia citricarpa, the citrus black pathogen. Phytopathology 54:64-67. 1964a.

McONIE, K.C. Orchard development and discharge of ascospores of Guignardia citricarpa and the onset of infection in relation to the control of citrus black spot. Phytopathology 54:1448-1453. 1964b.

MONDAL, S.N. \& TIMMER, L.W. Environmental factors affecting pseudothecial development and ascospore production of Mycosphaerella citri, the causal of citrus greasy spot. Phytopathology 92:1267-1275. 2002.

PERES, N.A.R. \& TIMMER, L.W. Citrus black spot caused by Guignardia citricarpa. CABI Crop Protection Compendium. CAB International, Oxford. 2003.

PINKERTON, J.N., JOHNSON, K.B., STONE, J.K. \& IVORS, K.L. Factors affecting the release of ascospores of Anisogramma anomala. Phytopathology 88:122 128. 1998a.

PINKERTON, J.N., JOHNSON, K.B., STONE, J.K. \& IVORS, K.L. Maturation and seasonal discharge pattern of ascospores of Anisogramma anomala. Phytopathology 88:1165-1173. 1998 b.

REIS, R.F., GOES, A. \& PEREIRA, G.T. Efeito da aplicaçâo de oxicloreto de cobre em diferentes épocas no controle da mancha preta dos citros causada por Guignardia citricarpa. Summa Phytopathologica 29:12-18. 2003.

ROWE, R.C. \& BEUTE, M.K. Ascospore formation and discharge by Calonectria crotalariae. Phytopathology 65:393-398. 1975.

SCHUTTE, G.C., BEETON, K.V. \& KOTZE, J.M. Rind stippling on Valencia oranges by copper fungicides used for control of citrus black spot in South Africa. Plant Disease 81:851-854. 1997.

SMITH, J.H. A study of the effect of various disease control programs on spore releases of the citrus black spot pathogen Guignardia citricarpa Kiely. Proceedings of the International Society of Citriculture 1:351-352. 1996.

SPÓSITO, M.B. Dinâmica temporal e espacial da mancha preta (Guignardia citricarpa) e quantificação dos danos causados a cultura dos citros (Tese de Doutorado). Piracicaba. Escola Superior de Agricultura ‘Luiz de Queiroz’, Universidade de Sao Paulo, 2003.

SUTTON, T.B. Production and dispersal of ascospores and conidia by Physalospora obtuse and Botryosphaeria dothidea in apple orchards. Phytopathology 71:584-589. 1981.

SUTTON, B.C. \& WATERSTON, J.M. Guignardia citricarpa. Descriptions of Pathogenic Fungi and Bacteria, No. 85, CAB International, Wallingford. 1966.

WHITESIDE, J.O. Environmental factors affecting infection of citrus leaves by Mycosphaerella citri. Phytopathology 64:115-120. 1974. 